\title{
Vesicular stomatitis due to Indiana III (Alagoas/VSIV-3) is endemic in Brazilian state of Ceará
}

\author{
Célio Souza da Rocha ${ }^{1,2}$ (D) Ilanna Vanessa Pristo de Medeiros Oliveira ${ }^{1}$ (D) \\ Gabriela Hemylin Ferreira Moura ${ }^{(}$José Artur Brilhante Bezerra $\left.^{1(}\right)$ \\ Fernanda Cristina Macedo Rondon ${ }^{3}$ (i) David Caldas Vasconcelos ${ }^{2}$ (i) Mônica Marcos de Almeida ${ }^{2}$ (i) \\ Annira Aquino Cortez ${ }^{2}$ (i) Cecília Calabuig1 (i) João Marcelo Azevedo de Paula Antunes ${ }^{1^{*}}$ (D)
}

\author{
${ }^{1}$ Hospital Veterinário Jerônimo Dix-Huit Rosado Maia, Universidade Federal Rural do Semi-árido (UFERSA), 59625-900, Mossoró, RN, \\ Brasil. E-mail: joao.antunes@ufersa.edu.br. "Corresponding author. \\ ${ }^{2}$ Agência de Defesa Agropecuária do Estado do Ceará (ADAGRI), Fortaleza, CE, Brasil. \\ ${ }^{3}$ Universidade de Fortaleza (UNIFOR), Fortaleza, CE, Brasil.
}

\begin{abstract}
:
Although Northeast Brazil is considered free of foot and mouth disease (FMD) with vaccination, several economic and health damages are still recorded due to the occurrence of vesicular syndromes that can be evaluated, such as Vesicular Stomatitis (VS). Therefore, this study aimed to confirm the occurrence of this disease and to determine the predominant viral serotype in suspected cases notified to the Official Veterinary Service of Ceará in 2013 performing official diagnostic protocols recommended by the World Organization for Animal Health. After clinical and epidemiological investigation in 46 farms, 32 probable cases of VS were considered with 78 sampled animals, 65 bovines and 13 equines. Serum (54) and epithelium (24) samples were collected. Six (14.6\%) of 41 bovines and 8 (61.5\%) of 13 equines described seroconversion to Indiana Vesiculovirus (IVV) by viral neutralization. The IVV was detected in 15 (62.5\%) of 24 bovines epithelia using the indirect sandwich ELISA. Finally, positive epithelium underwent complement fixation test viral subtyping that identified the occurrence of Indiana III serotype (Alagoas/IVV-3) in 11 (73.3\%) of 15 previous positives cattle. These were the first confirmed cases of VS in Ceará with an official diagnosis of IVV-3, confirming the endemic character attributed to the state through previous unofficial serological surveys. The presence of VS is a continuing diagnostic challenge, given the risk of possible incursions of FMD. Vesicular stomatitis is recurrent and is a worrying in this area free of foot and mouth disease with vaccination that bring damage to producers and a maximum alert to the Sanitary Defense Organs in the face of a probable case of vesicular syndrome.
\end{abstract}

Key words: Vesiculovirus, official diagnosis, surveillance, bovines.

Estomatite vesicular causada pelo subtipo Indiana III (Alagoas/VVI-3)

é endêmica no estado do Ceará, Brasil

RESUMO: Embora o Nordeste do Brasil seja considerado livre de Febre Aftosa (FA) com a vacinação, ainda são registrados vários prejuízos econômicos e sanitários devido à ocorrência de síndromes vesiculares que precisam ser adequadamente avaliadas, como Estomatite Vesicular (EV). Portanto, este estudo teve como objetivo confirmar a ocorrência desta doença e determinar o sorotipo viral predominante em casos suspeitos notificados ao Serviço Veterinário Oficial do Ceará no ano de 2013 realizando protocolos oficiais de diagnóstico recomendados pela Organização Mundial de Saúde Animal. Após investigação clínica e epidemiológica em 46 propriedades rurais, foram considerados 32 casos prováveis de propriedade foco de EV com 78 animais amostrados, sendo 65 bovinos e 13 equídeos. Amostras de soro (54) e epitélio (24) foram coletadas. Análises sorológicas de $6(14,6 \%)$ de 41 bovinos e $8(61,5 \%)$ de 13 equídeos apresentaram soroconversão ao Vesiculovírus Indiana (VVI) por neutralização viral. O VVI foi detectado em 15 (62,5\%) de 24 epitélios bovinos usando ELISA indireto sanduíche. Por fim, amostras de epitélio positivas foram submetidas a subtipagem viral por fixação do complemento que identificou a ocorrência do sorotipo Indiana III (Alagoas/VVI-3) em 11 (73,3\%) de bovinos. Estes foram os primeiros casos confirmados de EV no estado do Ceará com diagnóstico oficial de VVI-3 confirmando o caráter endêmico atribuído ao Estado por meio de levantamentos sorológicos não oficiais anteriores. A presença de EV é um desafio diagnóstico contínuo, dado o risco de possivveis incursões de FA. A Estomatite Vesicular é recorrente e preocupante nesta área livre de FA com vacinação pois, além de prejuizos aos produtores, traz um alerta máximo aos Órgãos de Defesa Sanitária diante de um caso provável de síndrome vesicular. Palavras-chave: vesiculovirus, diagnóstico oficial, vigilância, bovinos. 


\section{INTRODUCTION}

Vesicular stomatitis virus (VSV) infection in animals and humans occurs due to the presence of VSV, order Mononegavirales, family Rhabdoviridae, and genus Vesiculovirus, which is classified into 2 serogroups: New Jersey (NJ) virus, which is exotic in Brazil, and Indiana virus, which is present in Brazil and subdivided into the following 3 subtypes: Indiana I virus (Classical, VSIV-1), Indiana II virus (Cocal, VSIV-2), and Indiana III virus (Alagoas, VSIV3) (BEZERRA et al., 2018). These Vesiculovirus infections are clinically similar to foot-and-mouth disease (FMD) and should be distinguished in the susceptible species, as it restricts the trade and transit of animals until the presence of definitive confirmation by official laboratories (MAPA, 2009). Its socioeconomic importance is related to it being a zoonotic disease and causing vesicular lesions that affect herd productivity (GOODGER et al.,1985).

Epidemiologically important variants of the vesicular stomatitis (VS) in Brazil are the Indiana II and III viral subtypes. The Indiana II viral subtype was isolated in the states of São Paulo and Rio Grande do Sul in two separate episodes with 10-year difference and with no evidence of epidemiological connection between them (LÓPEZ-INZAURRALDE, 1997; CLEMENTINO et al., 2014). In 1998 and 1999, in the states of Paraná and Santa Catarina, two outbreaks of $E V$ were recorded by the Indiana II viral subtype, and until 2011, there was no record of this viral subtype in the country. The Indiana I viral subtype was never detected in Brazil (MAPA, 2012). Definitions of confirmed cases of Vesiculovirus in the country should consider the endemic occurrence of the Indiana III viral subtype, sporadic occurrence of the Indiana II viral subtype, and exotic condition of the Indiana I viral subtype and $N J$ serotype (MAPA, 2012).

The VSV infection is endemic to the northeast and north regions of Brazil (MAPA 2012) as shown by experimental protocols in the field or scientific/research protocols; however, reports of officially diagnosed cases or outbreaks of $V S V$ infection are scarce. LUNKES et al. (2016) investigated $V S I V-3$ viral circulation in three Brazilian regions and observed that the northeastern region had a broader viral activity than the centerwest and south regions. According to the official data, several suspected cases are attributed to other infectious or noninfectious causes; on the contrary, the underreporting of $V S V$ probably also occurs, contributing to an incomplete knowledge of the actual epidemiological situation (CARGNELUTTI et al., 2014). Indiana III has been detected recently in
Paraíba and Rio Grande do Norte (CARGNELUTTI et al., 2014; BEZERRA et al., 2018), neighboring states that border the State of Ceará, indicating that this region is endemic for $V S I V-3$.

As with FMD, strategies are needed to prevent the occurrence of outbreaks and eradicate the confirmed outbreaks of VS, such as active or passive surveillance and strict sanitary control. Prevention and eradication of VS are directly associated with actions performed by the government, such as the Ministry of Agriculture, Livestock, and Supply in close collaboration with all Official Veterinary Services (OVS) of the Brazilian states to detect any vesicular disease suspicion (LAGUARDIA-NASCIMENTO et al., 2016).

Impacts related to VS go beyond the health order with the onset of clinical symptoms but also generate financial impacts on producers (rural property interdiction; reduced production; restricted transit of products and by-products, vehicles and people; etc) and to the State that will promote the use of resources to counter the outbreaks. Therefore, the present study investigated the occurrence of VS from the notifications of suspected cases of vesicular disease submitted to the OVS of Ceará State with the objective of confirming the epidemiological condition of the state for VS for the first time using official diagnostic protocols that detect, besides viral circulation, the predominant serotype in the foci.

\section{MATERIALS AND METHODS}

All procedures followed the guidelines established by the Plan of Action for Foot-and-Mouth Disease (Volume I) (MAPA, 2009). All samples were tested following the diagnostic protocols recommended by the Manual of Diagnostic Tests and Vaccines for Terrestrial Animals (OIE, 2015).

The state has an area of $148,886.3 \mathrm{~km}^{2}$, equivalent to $9.58 \%$ of the area belonging to the northeast region of Brazil and $1.75 \%$ of the total area of Brazil. Hence, Ceará is the 4th largest state in the northeast region and the 17th state in Brazil that has territorial extension of a herd of animals susceptible to vesicular diseases, including the following: 2.546 .134 cattle, 2.027 buffalos (Bubalus bubalis), 2.098.893 sheep, 1.167.731 pigs, 1.024.594 goats, 194.465 asinines, 138.346 horses, and 80.741 mules (IPECE 2013). In 2013, the OVS of the state of Ceará received 46 reports of suspected cases of vesicular disease (Figure 1) where epidemiological investigations were conducted to confirm the probable cases with samples collected and sent to the National 
Agricultural and Livestock Laboratory (LANAGRO) in Pedro Leopoldo, Minas Gerais, and Belém, Pará, for the official confirmatory diagnosis. Initially, the investigated animals were mechanically restrained and clinically examined for signs of vesicular disease. In the absence of compatible clinical signs and associated epidemiological associations to vesicular diseases, the case was considered a discarded vesicular disease presenting a final clinical-epidemiological diagnosis. In the present study, 32 farms were selected, totaling 78 sampled animals, 65 cattle and 13 horses with clinical symptoms suggestive of vesicular syndrome.

When animals presented with symptoms associated with vesicular diseases, samples were collected according to the degree of preservation or cicatrization of the vesicles. In bovines with intact or recently ruptured vesicles, approximately $2 \mathrm{~g}$ of the epithelial tissue was collected and stored in sterile test tubes with vallee liquid with a $\mathrm{pH}$ of 7.4-7.8 and sent cooled to the laboratory to determine the presence of FMD and VS using sandwich indirect enzyme-linked immunosorbent assay (ELISA) (confirmatory test). In cases where the tested samples were positive in the confirmatory test, the identification of the infecting viral subtype would be performed: serotype positive samples for the Indian serotype underwent vesicular virus subtyping using the $50 \%$ complement fixation method and passage in baby hamster kidney cell cultures (lineage 21).

In animals (bovines and horses) with shallow healing (healing/healed ulcers), approximately $10 \mathrm{~mL}$ of blood was collected in vacuum tubes without anticoagulant, and this blood was centrifuged for serum extraction and sent to the laboratory to establish the paired serological diagnosis, including a set of reagents (proteins 3ABC, 3D, 2C, 3B and $3 \mathrm{~A}$ of $\mathrm{FMD}$ ) for in vitro detection of antibodies through the ELISA 3ABC/EITB and ELISA 3ABC (MET/LDDV/PL/029 V.1) and $V S V$ using viral neutralization (MET/LDDV/PL/023 V.2). Paired blood sampling was performed 15 days after the initial collection and if seroconverted titers were more than $4 \times$ positive (confirmatory test). In these bovines, oesophageal-pharyngeal fluid (OPF) samples were collected through a probang collecting cup, stored in a phosphate-buffered medium of equal volume, and sent cooled to the laboratory for molecular diagnosis using real-time quantitative reverse transcription polymerase chain reaction (qRT-PCR) for FMD.

Samples collected with properties suspicious for vesicular syndromes were closely monitored biweekly until laboratory results were reported. During the epidemiological investigation, active surveillance was conducted on rural properties

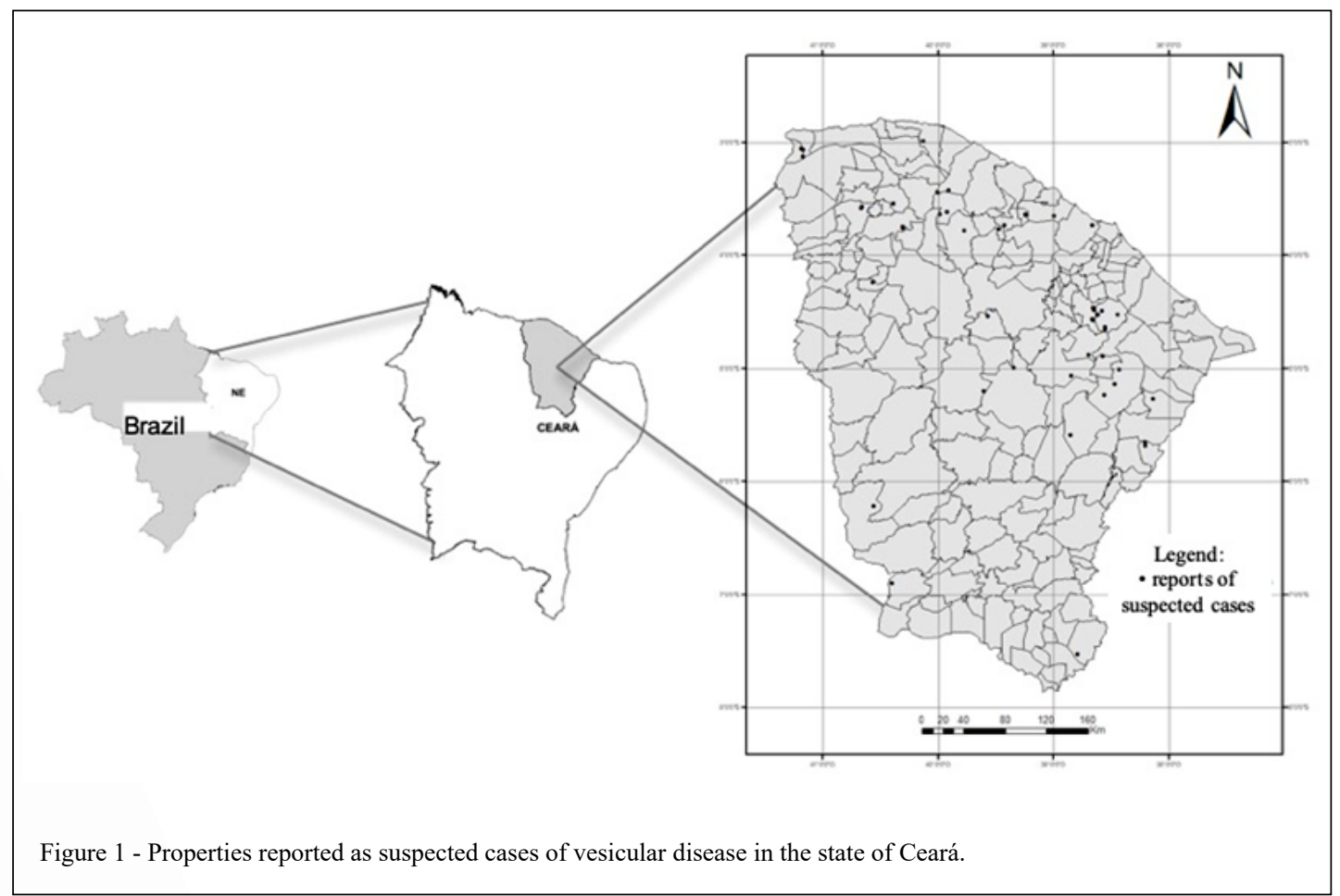

Ciência Rural, v.50, n.6, 2020. 
located within a $3-\mathrm{km}$ radius of the probable case. Laboratory confirmed properties as a focus of VS were blocked with traffic restrictions, and biosafety measures and health education were performed and then released 21 days after the clinical cure of the last symptomatic animal.

A questionnaire was applied using qualitative variables to identify the possible risk factors for the occurrence of VS during the outbreak to assist in the epidemiological investigation. Contingency tables were created between the categorical variables (yes or no), and value of the $\chi^{2}$ test was assessed to identify possible differences in the proportions of independent variables between the focus and non-focus rural properties. For this purpose, the statistical software IBM SPSS Statistics V22.0 was used. During all analyses, $\mathrm{p} \leq 0.05$ was considered statistically significant. The CEUA (Committee on Ethics and Animal Use from UFERSA) approved the project (number 23091.003999/2016-3), and written informed consent was obtained from each participant before enrollment. The property owner or farm manager was asked to answer questions about epidemiological practices and to supply information about probable cases of vesicular syndrome on the property. Observations and responses were entered into a database.

\section{RESULTS}

Among the reported properties, after the clinical inspection and epidemiological investigation, $30.4 \%$ (14/46) were considered cases of non-vesicular disease with the following diagnoses: pododermatitis (7), trauma (3), and absence of symptoms of vesicular diseases (4). The properties considered probable cases of vesicular disease accounted for $69.6 \%$ of the total (32/46) number and presented at least 1 symptomatic animal, with signs such as lameness, sialorrhea, low body score, rectal temperature of $39.9^{\circ} \mathrm{C}$, and presence of lesions in: interdigital space, hoof, coronet, pinnae, udder, teats, lips, tongue, and oral that varied from intact to ruptured or healing vesicles, cavity that varied between the integral vesicles. In total, 690 animals (susceptible species) were examined, and 78 samples were collected ( 65 bovines and 13 equines).

Of the 65 cattle sampled, 41 had healed lesions collected from blood serum for viral neutralization testing. The remaining 24 cattle had intact or recently ruptured oral and interdigital vesicles and were submitted to epithelium collection for indirect sandwich ELISA. All 13 symptomatic horses had healed lesions and the collected serum underwent viral neutralization analysis.
The animals blood serum were submitted to paired serological tests (viral neutralization), and, specifically in cattle, the OPF was collected. Initially, no bovine presented a positive result to the FMD virus using ELISA and qRT-PCR. When the serum samples were tested for $V S V$, it was observed that $14.6 \%(6 / 41)$ of the cattle and $61,5 \%(8 / 13)$ of the equidae ( 7 equines and 1 mule) collected presented an equal or better seroconversion four times compared to the first collection through titration (Table 1).

For the analysis of virus of FMD and VSV, only bovine whole epithelium samples (with intact or recently ruptured vesicles) were submitted to the virus typing test using indirect sandwich ELISA with passage in BHK cell (lineage 21) (Table 2). Results demonstrated that $62.5 \%(15 / 24)$ had a positive result, with an average optical density $>0.300$ for the Indiana viral serotype. All serotypes of Aphthovirus $(\mathrm{A}, \mathrm{O}, \mathrm{C})$ and Vesiculovirus $N J$ had negative results. In two properties, 2 bovines were positive for the Indiana viral serotype, confirming by molecular diagnosis using qRT-PCR of the epithelium. Finally, 11 of the 15 Indiana viral serotype-positive epithelial samples underwent viral subtyping using the 50\% complement fixation method with BHK cell passage (lineage 21) for the identification of the infecting subtype. All samples confirmed Indiana III as the agent causing the infection (Table 2).

Regarding the epidemiological questionnaire, no results could determine the existence of specific risk factors for the occurrence of VS (for all variables in table $3, \mathrm{~N}=32$, degree of freedom $=1, \mathrm{p}>0.05$ ).

\section{DISCUSSION}

As previously described by FERRIS et al. (2012) and ARRUDA et al. (2015), cattle and horses are more frequently affected by the clinical form of VS with higher morbidity among the equine population, and this situation was also observed in the present study with the occurrence of symptomatic animals in $14.67 \%(65 / 443)$ of cattle and $43.33 \%$ $(13 / 30)$ of equines.

CARGNELUTTI et al. (2014) described a high risk of infection in equines in states neighboring Ceará, and the rearing of cattle and horses is a risk factor for $V S I V$-3 (LUNKES et al., 2016). In both species, there was reactivity for all subtypes. In cattle, the results demonstrated seroconversion to Indiana I (3), Indiana II (1), Indiana III (2), and in equidae results demonstrated seroconversion to Indiana I (4); Indiana III (7); and Indiana II and III (4); (Table 1). 
Table 1 - Seroconversion for Vesicular stomatitis virus with cicatrized lesions (viral neutralization).

\begin{tabular}{|c|c|c|c|c|c|c|c|c|c|c|}
\hline \multirow[t]{2}{*}{ Farms } & \multirow[t]{2}{*}{ Specie } & \multicolumn{3}{|c|}{----------------Indiana I---------------- } & \multicolumn{3}{|c|}{------------Indiana II------------ } & \multicolumn{3}{|c|}{------------Indiana III------------ } \\
\hline & & IS $^{1}$ & $\mathrm{PS}^{2}$ & $\mathrm{SC}^{3}$ & IS & PS & $\mathrm{SC}$ & IS & PS & $\mathrm{SC}$ \\
\hline Caucaia & Equ & 30.1 & 79.4 & 2.6 & 19.9 & 316.2 & 15.8 & 39.8 & 2511.8 & 63.0 \\
\hline \multirow[t]{2}{*}{ Chaval } & Bov & 239.8 & 1288.2 & 5.3 & 316.2 & 954.9 & 3.0 & 2570.3 & 11.4 & 0.0 \\
\hline & Bov & 79.4 & 323.5 & 4.0 & 158.4 & 478.6 & 3.0 & 2570.3 & 39.8 & 0.0 \\
\hline Miraíma & Bov & 239.8 & 1288.2 & 5.3 & 323.5 & 1258.9 & 3.8 & 2570.3 & 2511.8 & 0.9 \\
\hline \multirow[t]{4}{*}{ Ocara } & Equ & 478.6 & 323.5 & 0.6 & 954.9 & 630.9 & 0.6 & 158.4 & 2511.8 & 15.8 \\
\hline & Bov & 1000 & 645.6 & 0.6 & 158.4 & 316.2 & 1.9 & 158.4 & 2511.8 & 15.8 \\
\hline & Bov & 39.8 & 19.9 & 0.5 & 15.8 & 79.4 & 5.0 & 316.2 & 1258.9 & 3.9 \\
\hline & $\mathrm{Mul}^{8}$ & 79.4 & 1288.2 & 16.2 & 316.2 & 1258.9 & 3.9 & 2511.8 & 2511.8 & 1 \\
\hline \multirow{6}{*}{ São Luís do Curu } & Equ & 645.6 & 79.4 & 0.1 & 2570.3 & 158.4 & 0.0 & 158.4 & 2511.8 & 15.8 \\
\hline & Equ & 323.5 & 1288.2 & 3.9 & 158.4 & 1258.9 & 7.9 & 158.4 & 2511.8 & 15.8 \\
\hline & Bov & 1288.2 & 79.4 & 0.0 & 158.4 & 630.9 & 3.9 & 158.4 & 1258.9 & 7.9 \\
\hline & Equ & 1288.2 & 1288.2 & 1 & 158.4 & 2511.8 & 15.8 & 158.4 & 2511.8 & 15.8 \\
\hline & Equ & 398.1 & 79.4 & 0.1 & 158.4 & 2511.8 & 15.8 & 158.4 & 2511.8 & 15.8 \\
\hline & Equ & 794.3 & 39.8 & 0.0 & 158.4 & 316.2 & 1.9 & 158.4 & 2511.8 & 15.8 \\
\hline \multirow{2}{*}{ Total } & & & & 4:3Bov; & & & 5: $4 \mathrm{Equ}$ & & & 9: 7 Equ; \\
\hline & & & & $1 \mathrm{Mul}$ & & & $1 \mathrm{Bov}$ & & & 2 Bov \\
\hline
\end{tabular}

Our positive results for $V S V$ may be related to the outbreaks described in the states of Paraíba and Rio Grande do Norte, with the State of Ceará bordering these two states (CARGNELUTTI et al., 2014, BEZERRA et al., 2018). The results supports the opinion that VS is endemic in Northeast of Brazil (DE STEFANO et al., 2003) who reported seropositivity for Indiana $I$ in $2.5 \%$ (28/1099) of cattle tested for VS in São Paulo; although, with the absence of clinical symptoms of vesicular diseases in this animal. Moreover, ARRUDA et al. (2015) demonstrated animals with titers for Indiana $I$ and $I I$, but the seroconversion in this case was restricted only to the equine species. According to BEZERRA et al. (2018), animals seroconverting to other viral subtypes with higher $V S I V-3$ antibody titers indicates an immune response to $V S I V-3$ infection whose antibodies cross-react with the other virus/serotypes.

The state of Ceará is considered an endemic area for $V S V$ with a repeated presence of the disease in the nonofficial diagnoses (LOPEZINZAURRALDE, 1997; LUNKES et al., 2016). In this case, it is common to find serological reactive animals with persistent neutralizing antibodies. In the endemic regions, the pattern of serological response to the disease shows a very variable behavior, making the interpretation of the tests used difficult; therefore, it is necessary to take into account the occurrence of cross-reaction between the different serotypes of the VS. Additionally, positive serological results for Indiana I viral subtype, exotic in the country, without confirmation in isolation or PCR are insufficient to declare focus, but serve as a warning to OVS (MAPA, 2012).

The present study demonstrated that after a 17-year unrecorded time lapse through the serological screening tests, it would still be possible to state that the virus continues to circulate in the state, this time being detected reactivity also in symptomatic equidae. These findings were corroborated by the use of confirmatory tests performed after the screening tests. The persistence of the Indiana III viral serotype in the State of Ceará over the years and in the border states (CARGNELUTTI et al., 2014; BEZERRA et al., 2018) suggested that VS represents the most frequent and impacting vesicular syndrome in a region free of foot-and-mouth vaccination. We believed that the hot climate in these states favors the proliferation of insects, which are probably an important means of viral propagation, being one of reasons for its viral maintenance (REIS JR et al., 2009). 
Table 2 - Research of Foot Mouth Diseases (FMD) and Vesicular Stomatitis Viruses (VSV) from oral and interdigital bovine epithelium (with intact or recently ruptured vesicles).

\begin{tabular}{|c|c|c|c|c|c|c|}
\hline \multirow[t]{3}{*}{ Municipallity (farms) } & \multicolumn{5}{|c|}{ Typification of FMD and VSV-indirect ELISA Sandwich } & \multirow{3}{*}{$\begin{array}{c}\text { Viral subtype with } \\
\text { complement fixation text } 50 \% \\
\text { VSIV }^{6}\end{array}$} \\
\hline & \multicolumn{3}{|c|}{---------------------FMD------------------ } & \multicolumn{2}{|c|}{----------------VS---------------- } & \\
\hline & $\mathrm{O}^{1}$ & $\mathrm{~A}^{2}$ & $\mathrm{C}^{3}$ & $\mathrm{NJ}^{4}$ & $I^{5}$ & \\
\hline \multirow[t]{2}{*}{ Aracoiaba } & $\mathrm{N}^{7}$ & $\mathrm{~N}$ & $\mathrm{~N}$ & $\mathrm{~N}$ & 0.939 & Indiana 3 \\
\hline & $\mathrm{N}$ & $\mathrm{N}$ & $\mathrm{N}$ & $\mathrm{N}$ & 0.939 & Indiana 3 \\
\hline Coreaú & $\mathrm{N}$ & $\mathrm{N}$ & $\mathrm{N}$ & $\mathrm{N}$ & 1.727 & Indiana 3 \\
\hline Ibicuitinga & $\mathrm{N}$ & $\mathrm{N}$ & $\mathrm{N}$ & $\mathrm{N}$ & 1.299 & Indiana 3 \\
\hline \multirow[t]{2}{*}{ Morada Nova } & $\mathrm{N}$ & $\mathrm{N}$ & $\mathrm{N}$ & $\mathrm{N}$ & 1.14 & Indiana 3 \\
\hline & $\mathrm{N}$ & $\mathrm{N}$ & $\mathrm{N}$ & $\mathrm{N}$ & 1,14 & Indiana 3 \\
\hline Morada Nova & $\mathrm{N}$ & $\mathrm{N}$ & $\mathrm{N}$ & $\mathrm{N}$ & $\mathrm{N}$ & $\mathrm{NA}^{8}$ \\
\hline Ocara & $\mathrm{N}$ & $\mathrm{N}$ & $\mathrm{N}$ & $\mathrm{N}$ & 1.095 & Indiana 3 \\
\hline Ocara & $\mathrm{N}$ & $\mathrm{N}$ & $\mathrm{N}$ & $\mathrm{N}$ & 0.878 & Indiana 3 \\
\hline \multirow[t]{5}{*}{ São Gonçalo do Amarante } & $\mathrm{N}$ & $\mathrm{N}$ & $\mathrm{N}$ & $\mathrm{N}$ & 0.783 & $\mathrm{NA}^{8}$ \\
\hline & $\mathrm{N}$ & $\mathrm{N}$ & $\mathrm{N}$ & $\mathrm{N}$ & $\mathrm{N}$ & $\mathrm{NA}^{8}$ \\
\hline & $\mathrm{N}$ & $\mathrm{N}$ & $\mathrm{N}$ & $\mathrm{N}$ & $\mathrm{N}$ & $N A^{8}$ \\
\hline & $\mathrm{N}$ & $\mathrm{N}$ & $\mathrm{N}$ & $\mathrm{N}$ & $\mathrm{N}$ & $\mathrm{NA}^{8}$ \\
\hline & $\mathrm{N}$ & $\mathrm{N}$ & $\mathrm{N}$ & $\mathrm{N}$ & $\mathrm{N}$ & $N A^{8}$ \\
\hline \multirow[t]{2}{*}{ São Luís do Curu } & $\mathrm{N}$ & $\mathrm{N}$ & $\mathrm{N}$ & $\mathrm{N}$ & $\mathrm{N}$ & $N A^{8}$ \\
\hline & $\mathrm{N}$ & $\mathrm{N}$ & $\mathrm{N}$ & $\mathrm{N}$ & 1.271 & Indiana 3 \\
\hline \multirow[t]{3}{*}{ São Luís do Curu } & $\mathrm{N}$ & $\mathrm{N}$ & $\mathrm{N}$ & $\mathrm{N}$ & $\mathrm{N}$ & $\mathrm{NA}^{8}$ \\
\hline & $\mathrm{N}$ & $\mathrm{N}$ & $\mathrm{N}$ & $\mathrm{N}$ & $\mathrm{N}$ & $N A^{8}$ \\
\hline & $\mathrm{N}$ & $\mathrm{N}$ & $\mathrm{N}$ & $\mathrm{N}$ & $\mathrm{N}$ & $\mathrm{NA}^{8}$ \\
\hline \multirow[t]{2}{*}{ São Luís do Curu } & $\mathrm{N}$ & $\mathrm{N}$ & $\mathrm{N}$ & $\mathrm{N}$ & 1.282 & Indiana 3 \\
\hline & $\mathrm{N}$ & $\mathrm{N}$ & $\mathrm{N}$ & $\mathrm{N}$ & 1.282 & Indiana 3 \\
\hline \multirow[t]{3}{*}{ Sobral } & $\mathrm{N}$ & $\mathrm{N}$ & $\mathrm{N}$ & $\mathrm{N}$ & 1.065 & $\mathrm{NA}^{8}$ \\
\hline & $\mathrm{N}$ & $\mathrm{N}$ & $\mathrm{N}$ & $\mathrm{N}$ & 1.065 & $N A^{8}$ \\
\hline & $\mathrm{N}$ & $\mathrm{N}$ & $\mathrm{N}$ & $\mathrm{N}$ & 1.065 & $N A^{8}$ \\
\hline
\end{tabular}

${ }^{1} \mathrm{O}=$ Serotype $\mathrm{O},{ }^{2} \mathrm{~A}=$ Serotype $\mathrm{A},{ }^{3} \mathrm{C}=$ Serotype $\mathrm{C},{ }^{4} \mathrm{NJ}=$ New Jersey serotype, ${ }^{5} \mathrm{I}=$ Indiana, ${ }^{6} \mathrm{VSIV}=$ Indiana Vesiculovirus, ${ }^{7} \mathrm{~N}=$ Negative, ${ }^{8} \mathrm{NA}=$ Not Applicable.

It was the first time that the OVS employed the use of collection and diagnostic techniques for the viral isolation or detection of genetic material for the confirmation of VS outbreaks in the State of Ceará. The Indiana III viral serotype has been frequently detected in the northeastern states in recent years, confirming its endemic trait in the region. The agent was isolated from the bovine tongue and serum epithelium in 2010 and 2016 in Paraíba (CLEMENTINO et al., 2014; BEZERRA et al., 2018) and in 2013 in Maranhão (ARRUDA et al., 2015). CARGNELUTTI et al. (2014) also detected the presence of VSIV in vesicular fluid and oral epithelium samples of equine and bovine in the states of Rio Grande do Norte and Paraíba. The present study reinforces previous findings and contributed to a better understanding of the epidemiological studies of VS in the region and confirmation of viral circulation in these states. This is the first report on the occurrence of VS in the State of Ceará using an official confirmatory diagnosis with $V S I V$ detection in the epithelial samples using the protocols recommended by the Office International des Epizooties (OIE), besides confirming the viral circulation in the state described by LOPEZINZAURRALDE (1997) through the previous serological tests and predominance of the Indiana III/ Alagoas ( $V S I V-3)$ subtype during the outbreaks.

All variables in table 3 epidemiological questionnaire couldn't determine the existence of specific risk factors for the occurrence of $V S V$. Nevertheless, the variables "Do farm animals participate in agglomeration events?" presented a marginally significant difference between the foci and non-foci properties with $\mathrm{p}=0.098$ (Table 3), suggesting that with a larger sample number, it would be possible to present significant differences.

The reduced number of sampled properties may have been a limiting factor despite the fact that 
the research was conducted on all properties with suspected vesicular diseases. This situation indicated the need for a greater number of substantiated reports so that explanatory variables can serve as a preventive basis for epidemiological studies. During the epidemiological investigation of outbreaks in Paraíba, CLEMENTINO et al. (2014) concluded that it was impossible to identify the origin of the virus as no significant entry of VS-susceptible animals into areas within $3 \mathrm{~km}$ from the outbreak was detected 30 days before disease onset. Several studies have reported that it is often impossible to identify the source of the infection and its reservoirs (DE STEFANO et al., 2002; SEPÚLVEDA et al., 2007). Results not demonstrated direct relation to the studied variables (situations of possible viral transmission by direct or indirect contact); however, our study demonstrated a persistence of viral circulation in the state of Ceará that may be associated with climatic and health factors that facilitate viral maintenance and dissemination in Northeast Brazil, such as the presence of insect vectors, animal trade with the absence of knowledge as regards sanitary conditions, low technification of the farms, and absence of animal quarantine, factors that were already studied previously (ZIMMER et al., 2013; CLEMENTINO et al., 2015; LUNKES et al., 2016).

The field diagnosis through experimental research conducted by research institutions has its importance; however, the detection of the Indiana III viral serotype using laboratory techniques recommended by the OIE for the confirmation of the $V S V$ and identification of the infectious agent produced results supported by the organ and contributed to the expansion of scientific knowledge about the actual epidemiological situation of VS in Ceará and Brazil, which confirmed the viral circulation in this state and the endemic feature of the VS in this region. In addition it was demonstrated the efficacy of the surveillance system in confirming a vesicular syndrome suggesting that the Ceará state is able to act in similar protocols (such as FMD).

\section{CONCLUSION}

These were the first cases officially confirmed a long-standing suspicion that VS is endemic in the Brazilian state of Ceará and that, based on official OIE assays, the predominant serotype (as of 2013) was Indiana III (Alagoas/ VSIV-3). Finally, the research showed that, even considering the importance given by governments to FMD and its consequences for the productive sector due to the potential for the spread of the disease and the economic potential of exports from Brazilian livestock, we suggested that in the Northeast and in the Ceará State, free of FMD with vaccination, where this economic characteristic is not exponential, VS can be considered the possible vesicular syndrome with the highest real risk to susceptible herds.

Table 3 - Epidemiological questionnaire during investigation of probable cases of vesicular syndrome.

\begin{tabular}{|c|c|c|c|c|c|}
\hline Questions & & Non-focus & Focus & Total & $\chi^{2}$ \\
\hline \multirow{2}{*}{ Do you use neighboring facilities or equipment or vice-versa? } & Yes & 3 & 10 & 13 & \multirow{2}{*}{0.163} \\
\hline & No & 9 & 10 & 19 & \\
\hline \multirow{2}{*}{ Has there been a recent influx of vehicles that may carry infectious agents? } & Yes & 4 & 4 & 8 & \multirow{2}{*}{0.114} \\
\hline & No & 8 & 16 & 24 & \\
\hline \multirow{2}{*}{$\begin{array}{l}\text { Has anyone on the property who has access to susceptible animals visited another } \\
\text { farm with susceptible animals in the last } 30 \text { days? }\end{array}$} & Yes & 10 & 13 & 23 & \multirow{2}{*}{0.264} \\
\hline & No & 2 & 7 & 9 & \\
\hline \multirow{2}{*}{$\begin{array}{l}\text { Did you receive visits from people who work or have access to susceptible animals } \\
\text { from other farms? }\end{array}$} & Yes & 9 & 17 & 26 & \multirow{2}{*}{0.483} \\
\hline & No & 3 & 3 & 6 & \\
\hline \multirow{2}{*}{ Is there a history of feeding change? } & Yes & 0 & 3 & 3 & \multirow{2}{*}{0.159} \\
\hline & No & 12 & 17 & 29 & \\
\hline \multirow{2}{*}{ Do you use labor from neighbors or vice-versa? } & Yes & 4 & 11 & 15 & \multirow{2}{*}{0.234} \\
\hline & No & 8 & 9 & 17 & \\
\hline \multirow{2}{*}{ Do farm animals participate in agglomeration events? } & Yes & 0 & 4 & 4 & \multirow{2}{*}{0.098} \\
\hline & No & 12 & 16 & 28 & \\
\hline \multirow{2}{*}{$\begin{array}{l}\text { Proximity/ frontier of the farm with highways, dumps, airports, slaughterhouse, } \\
\text { dairy industry? }\end{array}$} & Yes & 2 & 9 & 11 & \multirow{2}{*}{0.102} \\
\hline & No & 10 & 11 & 21 & \\
\hline
\end{tabular}

Ciência Rural, v.50, n.6, 2020. 


\section{ACKNOWLEDGMENTS}

We thank the producers and third parties who notified the suspicions to the OVS; to all ADAGRI public servants who collaborated with field actions and sample collection; the National Agricultural Laboratories (LANAGRO) of Minas Gerais and Pará States, Brazil; to the entire ADAGRI management team from 2013 to 2016 that authorized the research. To Coordenação de Aperfeiçoamento de Pessoal de Nível Superior (CAPES) - Financing Code 001, for supporting the C.S.R., I.V.P.M.O., G.H.F.M. and J.A.B.B. with postgraduate fellowship.

\section{DECLARATION OF CONFLICT OF} INTERESTS

The authors declare no conflict of interest. The founding sponsors had no role in the design of the study; in the collection, analyses, or interpretation of data; in the writing of the manuscript, and in the decision to publish the results.

\section{AUTHORS' CONTRIBUTIONS}

All authors contributed to the study conception and design. Material preparation, data collection and analysis were performed by C.S.R., I.V.P.M.O., G.H.F.M., J.A.B.B., F.C.M.R., D.C,V., M.M.A., A.A.C. and C.C. The first draft of the manuscript was written by J.M.A.P. Antunes and all authors commented on previous versions of the manuscript. All authors read and approved the final manuscript.

\section{BIOETHICS AND BIOSSECURITY COMMITTEE APROVAL}

Animal rights were considered in this study and ethical guidelines of institutional animal ethics committee (CEUACommittee on Ethics and Animal Use from UFERSA) were followed for conducting the experiment through the number No. 23091.003999/2016-3.

\section{REFERENCES}

ARRUDA, R. C. N. et al. Stomatitis vesicular in cattle and horse in the Maranhão state. Pesquisa Veterinária Brasileira, v.35, n.5, p.391-395, 2015. Available from: <http://www.scielo.br/pdf/ pvb/v35n5/1678-5150-pvb-35-05-00391.pdf $>$. Accessed: Jan. 12, 2019. doi: 10.1590/S0100-736X2015000500001.

BEZERRA, C. S. et al. Epidemiological situation of vesicular stomatitis vírus infection in cattle in the state of Paraíba, semiarid region of Brazil. Preventive Veterinary Medicine, v.160, p.68-75, 2018. Available from: $<$ https://www.ncbi.nlm.nih.gov/pubmed/?te $\mathrm{rm}=.+$ Epidemiological + situation + of + vesicular + stomatitis $+\mathrm{v} \% \mathrm{C} 3$ $\%$ ADrus + infection + in + cattle + in + the + state + of + Para $\% \mathrm{C} 3 \% \mathrm{ADba}$ $\% 2 \mathrm{C}+$ semiarid + region + of + Brazil $>$. Accessed: Jan. 14, 2019. doi: 10.1016/j.prevetmed.2018.09.027

CARGNELUTTI, J. F. et al. Outbreaks of vesicular stomatitis Alagoas virus in horses and cattle in northeastern Brazil. Journal of Veterinary Diagnostic Investigation, v.26, n.6, p.788-794, 2014. Available from: <https://www.ncbi.nlm. nih.gov/pubmed/2527474>. Accessed: Feb. 09, 2019. doi: $10.1177 / 1040638714553428$.
CLEMENTINO, I. J. et al. First case report of vesicular stomatitis in the State of Paraiba, Brazil. Semina, v.35, n.5, p.2601-2606, 2014. Available from: <http://www.uel.br/revistas/uel/index.php/ semagrarias/article/view/14880/15273>. Accessed: Mar. 22, 2019. doi: $10.5433 / 1679-0359.2014 \mathrm{v} 35 \mathrm{n} 5 \mathrm{p} 2601$.

CLEMENTINO, I. J. et al. Characterization of cattle raising in Paraíba State, Northeastern Brazil. Semina, v.36, p.557-570, 2015. Available from: <http://www.uel.br/revistas/uel/index.php/ semagrarias/article/view/15771>. Accessed: Jan. 02, 2019. doi: 10.5433/1679-0359.2015v36n1p557.

DE STEFANO, E. et al. Vesicular stomatitis. Arquivos do Instituto Biológico de São Paulo, 69(3), 127-133, 2002. Available from: <https://www.researchgate.net/publication/295860158 ESTOMATITE_VESICULAR>. Accessed: Jan. 04, 2019.

DE STEFANO, E. et al. Vesicular stomatitis: serological survey in beef cattle from region of Araçatuba, São Paulo State, Brazil in 2000. Brazilian Journal of Veterinary Research and Animal Science, v.40, n.1, p.29-35, 2003. Available from: <http://www. scielo.br/scielo.php?script $=$ sci abstract\&pid $=\mathrm{S} 141395962003000$ 100003\&lng=en\&nrm=iso\&tlng=en>. Accessed: May, 08, 2018. doi: $10.1590 /$ S1413-95962003000100003.

FERRIS N. P. et al.. Development and laboratory evaluation of two lateral flow devices for the detection of vesicular stomatitis virus in clinical samples. Jounal of Virology Methods, v.180, p.96-100, 2012. Available from: <https://www.ncbi.nlm.nih.gov/pubmed/?t $\mathrm{erm}=$ Development + and + laboratory+evaluation + of + two + lateral + flow + devices + for + the + detection + of + vesicular + stomatitis + virus +in+clinical+samples $>$. Accessed: May, 09, 2019. doi: 10.1016/j. jviromet.2011.12.010.

GOODGER, W. J. et al.. Economic impact of an epizootic of bovine vesicular stomatitis in California. Journal of American Veterinary Medicine Association, v.186, n.4, p.370-373, 1985. Available from: <https://www.ncbi.nlm.nih.gov/pubmed/?term=E conomic + impact + of + an + epizootic + of + bovine + vesicular + stomatit is + in + California $>$. Accessed: Jul. 10, 2019.

IPECE - Institute of Research and Economic Strategy of Ceará. Statistical Yearbook of Ceará. Agropecuary and vegetal extraction - Flocks. 2013. Fortaleza, 01 Mar 2014. Available from: $<$ http://www2.ipece.ce.gov.br/publicacoes/anuario/anuario2013/ aspectosEconomicos/agropecuaria_extracao/rebanhos.htm>. Accessed: Jan. 01, 2018.

LAGUARDIA-NASCIMENTO, M., et al. Detection of multiple viral infections in cattle and buffalo with suspected vesicular disease in Brazil. Journal of Veterinary Diagnostic Investigation, v.28, n.4, p.377-381，2016. Available from: $<$ https://www.ncbi.nlm.nih.gov/pubmed/?term=Detection + of + m ultiple+viral+infections + in + cattle + and + buffalo + with + suspecte $\mathrm{d}+$ vesicular+disease+in+Brazil $>$. Accessed: Jan. 12, 2019. doi: $10.1177 / 1040638716645836$.

LOPEZ-INZAURRALDE, A. Special and temporal distribution of vesicular stomatitis in Brazil, 1964-1996. 1997. 68f. Thesis ( $\mathrm{PhD}$ in Veterinary Medicine) - Course of Animal Science, University Federal of Minas Gerais.

LUNKES, V. L. et al. Antibodies against vesicular stomatitis virus in horses from southern, midwestern and northeastern Brazilian States. Ciência Rural, v.46, n.8, p.1424-1429, 2016. Available from: $\quad<$ http://www.scielo.br/scielo.php?script=sci_arttext\&pid 
$=$ S0103-84782016000801424>. Accessed: Feb. 15, 2018. doi: $10.1590 / 0103-8478 \mathrm{cr} 20151135$.

MAPA - Ministério da Agricultura, Pecuária e Abastecimento. Foot-and-Mouth Disease Action Plan. Volume I. 2009. Brasília, 01 jul 2009. Available from: <http://www.agricultura.gov.br/ assuntos/sanidade-animal-e-vegetal/saude-animal/programas-desaude-animal/febre-aftosa/documentos-febre-aftosa/plano-deacao-para-febre-aftosa.pdf $>$. Accessed: Feb. 15, 2018.

MAPA - Ministry of Agriculture, Livestock and Supply. Case Definition of Vesicular Stomatitis and Vesicular Disease Flow. 2012. Brasília May, 2012 . Available from: $<\mathrm{http}: / / \mathrm{www} . a g e d$. ma.gov.br/files/2014/01/Memo-Circular-DSA-nº-68-de-03.05.12Definição-de-caso-de-estomatite-vesicular-SFAs-DDAs-Todas. pdf $>$. Accessed: Feb. 15, 2018.

OIE - World Organisation For Animal Health. Vesicular stomatitis. Manual of diagnostic tests and vaccines for terrestrial animals. 2015. Available from: <http://www.oie.int/fileadmin/Home/eng/
Health_standards/tahm/2.01.23_VESICULAR_STOMATITIS. pdf $>$. Accessed: Jan. 01, 2018.

REIS, J. L. et al. Transmission and pathogenesis of vesicular stomatitis viruses. Brazilian Journal of Veterinary Pathology, v.2, n.1, p.49-58, 2009. Available from: <https://bjvp.org.br/wpcontent/uploads/2015/07/V.2-N.1-12-20881_2009_12_30_29_6. pdf $>$. Accessed: Jan. 01, 2018.

SEPÚLVEDA, L. M. et al.. Rapid diagnosis of vesicular stomatitis vírus in ecuador by the use of polymerase chain reaction. Brazilian Journal of Microbiology, v.38, n.3, p.500-506, 2007. Available from: $\quad<$ http://dx.doi.org/10.1590/S1517-83822007000300022>. Accessed: Oct. 12, 2018.

ZIMMER, B. et al. Stability and inactivation of vesicular stomatitis virus, a prototype Rhabdovirus. Veterinary Microbiology, v.162, p.78-84, 2013. Available from: <https://www.ncbi.nlm.nih.gov/pu bmed/?term $=$ Stability + and + inactivation + of + vesicular + stomatitis + virus $\% 2 \mathrm{C}+\mathrm{a}+$ prototype + Rhabdovirus $>$. Accessed: Oct. 13, 2018. doi: 10.1016/j.vetmic.2012.08.023. 